Arif Zainudin,

arif zainudin88@yahoo.com

Program Studi Ilmu Pemerintahan

Universitas Pancasakti Tegal

\section{MODEL KELEMBAGAAN \\ PEMERINTAHAN DESA}

Pemerintah Desa ialah penyelenggaraan urusan pemerintahan dan kepentingan masyarakat setempat dalam sistem pemerintah Negara Kesatuan Republik Indonesia. Hakekatnya sebagai pemenuhan kebutuhan dasar masyarakatnya, atau sebagai unsur pemerintah yang melayani masyarakatnya. Sehingga Pemerintah Desa memiliki urusan yang dijadikan tugas bagi pemerintahan, seperti urusan tata pemerintahan, urusan pemberdayaan masyarakat desa, urusan kesejahteraan masyarakat dan urusan ketertiban lingkungan. Sehingga bentuk organisasi Pemerintahan Desa minimal harus mewakili urusan yang dimiliki pemerintahan Desa. Permasalahan dalam penelitian ini ialah bagaimana bentuk organisasi pemerintah desa pasca diterapkan UU No. 6 Tahun 2014 tentang Desa.

Maka dengan permasalahan tersebut penelitian ini memiliki tujuan yaitu, mengidentifikasi jenis pelayanan dasar pemerintahan desa, dan merencanakan model organisasi pemerintahan Desa. berdasarkan permasalahan tersebut maka penulis menggunakan pendekatan metode penelitian kualitatif, dengan strategi penelitian grounded theory sebagai suatu proses untuk memproduksi dan merancang sebuah model yang didasari oleh kategori-kategori interaksi sistem pemerintah.

Berdasarkan penelitian yang telah dilakukan maka Pemerintahan Desa memiliki jenis pelayanan administrasi yang berbentuk perizinan dan non-perizinan. Model organisasi pemerintahan Desa yang minimal harus dimiliki yaitu, Kepala Desa, Sekertaris, Kaur Umum, Kaur Keuangan, dan Kaur Perencanaan kemudian untuk unit teknis operasional dinamakan Kasi Pelayanan, Kasi Pemerintah dan Kasi Kesejahteraan. Karena menurut Permendagri No. 84 tahun 2015 tentang SOTK Pemerintah Desa memiliki 3 unit Kaur dan 3 unit Kasi.

Kata Kunci : Model Kelembagaan, Pemerintah Desa

\section{PENDAHULUAN}

Berdasarkan Undang-Undang No. 6 Tahun 2014 tentang Desa Psl. 1, pemerintahan Desa ialah penyelenggaraan urusan pemerintahan dan kepentingan masyarakat setempat dalam sistem pemerintah Negara Kesatuan Republik Indonesia. Latar belakang berdirinya sebuah pemerintahan desa di sebuah wilayah hakekatnya ialah sebagai pemenuhan kebutuhan dasar masyarakatnya, atau sebagai unsur pemerintah yang melayani masyarakatnya. Dalam proses pemenuhan kebutuhan dasar tentunya desa memiliki urusan untuk menjalankan fungsi dari pemerintahanya. Adapun urusan pemerintahan desa yakni urusan tata pemerintahan, urusan pemberdayaan masyarakat desa, urusan kesejahteraan masyarakat dan urusan ketertiban lingkungan. sementara ini urusan pemerintahan desa tersebut, menjadi unit dalam organisasi pemerintahan Desa. akan tetapi dengan adanya perubahan regulasi pengaturan Undang-Undang No. 6 Tahun 2014 
tentang Desa, menyebutkan bahwa struktur organisasi pemerintahan desa tidak harus merujuk kepada urusan yang dimlikinya. Namun Kepala Desa berhak mengusulkan struktur organisasi pemerintahan desa dan tata kerja (psl. 26 UU No. 6 Tahun 2014 tentang Desa).

Dengan adanya UU No. 6 Tahun 2014 tentang Desa mengatur kewenangan pemerintahan Desa. pasal 18 UU No. 6 Tahun 2014 tentang Desa, mengatur tentang klasifikasi bidang dalam pemerintahan Desa. adapun bidang tersebut yakni penyelenggaraan pemerintahan Desa, pelaksanaan pembangunan Desa, pembinaan kemasyarakatan desa dan pemberdayaan masyarakat Desa berdasarkan prakarsa masyarakat, hak asal usul dan adat istiadat desa. dengan pengaturan bidang dalam peraturan tersebut, maka struktur organisasi pemerintahan desa akan berganti yang sebelumnya unit teknis disebutnya Kepala urusan menjadi kepala bidang.

Menurut mithzberg dalam menentukan struktur organisasi ditentukan berdasarkan urusan dan kewenangan organisasi yang melekat. Dalam pemerintahan Desa berdasarkan UndangUndang No. 6 Tahun 2014 tentang Desa ada 4 (empat) kewenagnan yang melekat dalam pemerintahana Desa, hal tersebut yang perlu dijabarkan dalam bentuk organisasi pemerintahan Desa.

Sementara ini, sebelum adanya perubahan peraturan tentang Desa, pemerintahan desa menggunakan nama urusan desa sebagai unit teknis organisasi pemerintahan desa. seperti urusan tata pemerintahan, urusan pemberdayaan masyarakat desa, urusan kesejahteraan masyarakat, dan urusan ketertiban lingkungan.

Seperti model organisasi desa yang dimiliki oleh pemerintahan Desa Kemuning Kec. Kramat Kab. Tega dari salah satu desa yang masih menjalankan peraturan lama yakni nama unit struktur organisasi pemerintahan desa menggunakan urusan pemerintahan desa. oleh karena itu dengan adanya peraturan Undang-Undang No. 6 tahun 2014 tentang Desa, maka perlua dilakukan revitalisasi kelembagaan pemerintahan Desa. Sehingga model organisasi pemerintahan Desa kemuning dapat menampung kewenangan yang diamanahkan dalam peraturan tersebut.

\section{METODE}

Pendekatan penelitian yang digunakan dalam menyelesaikan permasalahan yakni pendekatan kualitatif. Berfungsi sebagai proses penelitian yang berdasarkan dari gejala sosial yang 
terjadi dalam proses-proses penelitian Creswell (2012:68).

Dalam melaksanakan penelitian ini digunakan metode grounded theory yang merupakan strategi penelitian yang di dalamnya peneliti "memproduksi" teori umum dan abstrak dari suatu proses, aksi atau interaksi tertentu yang berasal dari pandangan-pandangan partisipan.

\section{HASIL DAN PEMBAHASAN}

\section{Model Kelembagaan Berdasarkan}

\section{Permendagri No. 84 Tahun 2015}

\section{A. Desa Swadaya}

Desa Swadaya merupakan Desa yang masih tradisional dan masih cenderung terisolasi dari kehidupan luar Desa, dengan ciri-ciri Desa sebagai berikut :

Mata pencaharian penduduk masih sangat bergantung pada alam;
Bersifat subsistance farming (untuk pemenuhan kebutuhan sendiri);

Administrasi desa masih kurang baik; Lembaga desa belum berfungsi bahkan belum ada;

Pendidikan dan kesehatan masih rendah;

Akses menuju desa sangat sulit;

Masih memegang adat istiadat dengan patuh.

Desa Swadaya merupakan Desa Adat, sehingga perubahan sosial masyarakat ditentukan oleh budaya atau kebiasaan masyarakat tradisional. Menurut Psl. 11 ayat 5 Permendagri. No. 84 Tahun 2015 tentang Susunan Organisasi dan Tata Kerja Pemerintah Desa, unit organisasi yang harus dimilikinya ialah unit urusan berjumlah 2 (dua) dan 2 (dua) seksi. Adapun gambarnya dapat dilihat sebagai berikut.

\section{Model Kelembagaan Pemerintahan Desa Swadaya}

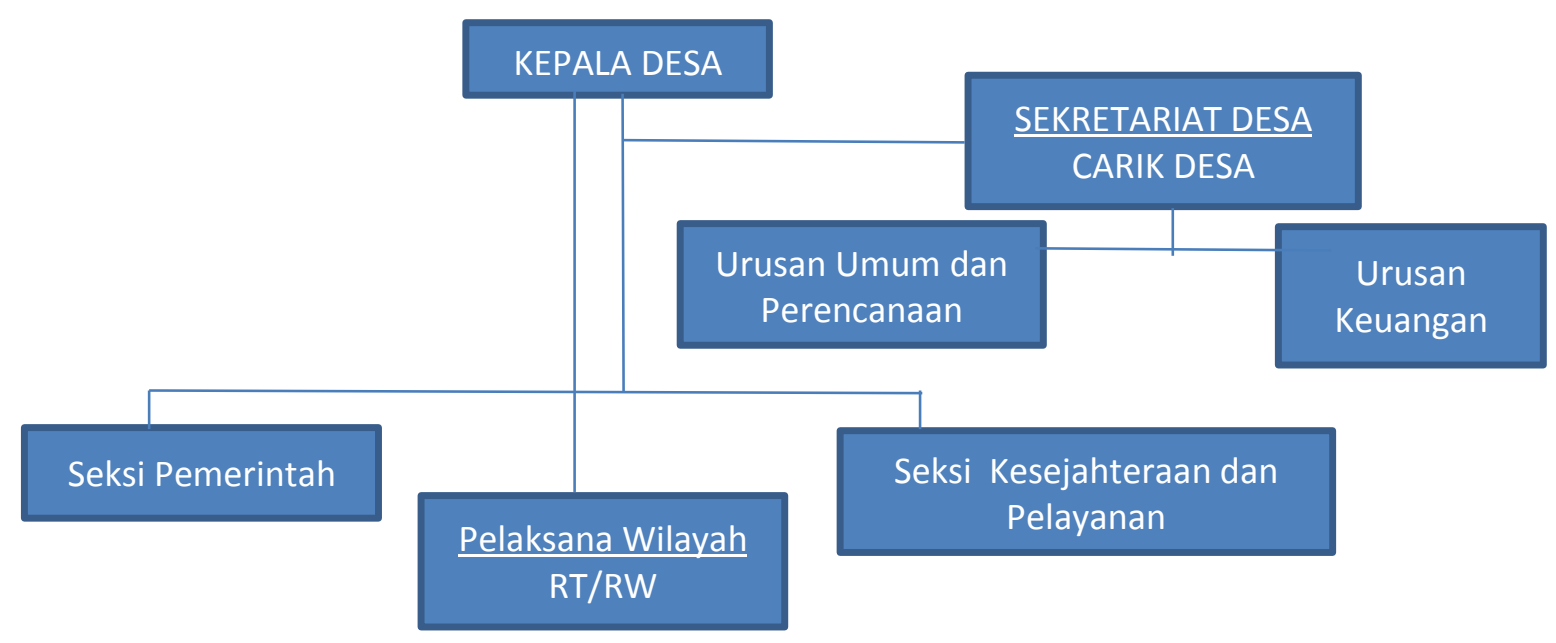




\section{B. Desa Swadaya}

Desa Swasembada merupakan Desa yang setingkat lebih maju dari Desa Swakarya, di mana adat istiadat masyarakat sudah tidak mengikat. Begitu pula dengan hubungan antar manusia yang sudah bersifat rasional. Mata pencarian penduduk sudah beragam dan bergerak ke sektor tertier. Teknologi baru sudah benar-benar dimanfaatkan di bidang pertanian sehingga produktivitasnya tinggi yang diimbangi dengan prasarana desa yang cukup.

Perkembangan ekonominya telah mengarah pada kegiatan regional dan nasional, minimal desa ini telah memiliki empat faktor strategis meliputi:

1. Prakarsa hasil produksi yang merangsang.

2. Teknik - teknik produksi yang selalu berubah-ubah sesuai dengan penemuan-penemuan baru.

3. Kemudahan akses transportasi dan akses komunikasi. (Koenjtaraningrat)

Dan Desa Swasembada memiliki norma yang melekat pada desa, norma tersebut antara lain:

Mata pencaharian di sektor tersier, yaitu sebagian besar penduduk bergerak di bidang perdagangan dan jasa.

Hasil desa yaitu, jumlah dari seluruh produksi desa yang dinyatakan dalam nilai rupiah di bidang pertanian, perkebunan, peternakan, perikanan, kerajinan atau industri kecil, perdagangan dan jasa sudah tinggi.

Adat istiadat dan kepercayaan penduduk sudah tidak mengikat lagi.

Kelembagaan dan pemerintahan desa sudah efektif baik dalam tugas dan fungsinya. Pembangunan pedesaan sudah direncanakan dengan sebaikbaiknya.

Pendidikan dan keterampilan penduduk tingkatnya sudah tinggi, lebih dari $60 \%$ penduduk telah menamatkan sekolah dasar.

Swadaya atau gotong royong masyarakat sudah manifest, artinya pelaksanaan dan cara kerja gotong royong berdasarkan musyawarah atau mufakat antara warga masyarakat dengan penuh rasa kesadaran dan tanggung jawab yang selaras dengan norma-norma perkembangan atau kemajuan zaman.

* Prasarana produksi, perhubungan, pemasaran dan sosial cukup memadai, serta hubungan dengan kota-kota sekitarnya berjalan lancar.

Dengan kriteria Desa Swasembada menurut psl 11 ayat 2 Permendagri. No. 84 Tahun 2015 tentang Susunan Organisasi dan Tata Kerja Pemerintah Desa, disebutkan bahwa dengan jenis 
desa swasembada memiliki 3 unit struktur organisasi pemerintah desa urusan dan 3 unit seksi untuk pelayanan sebagai berikut.

teknis pemerintah desa. Adapun model

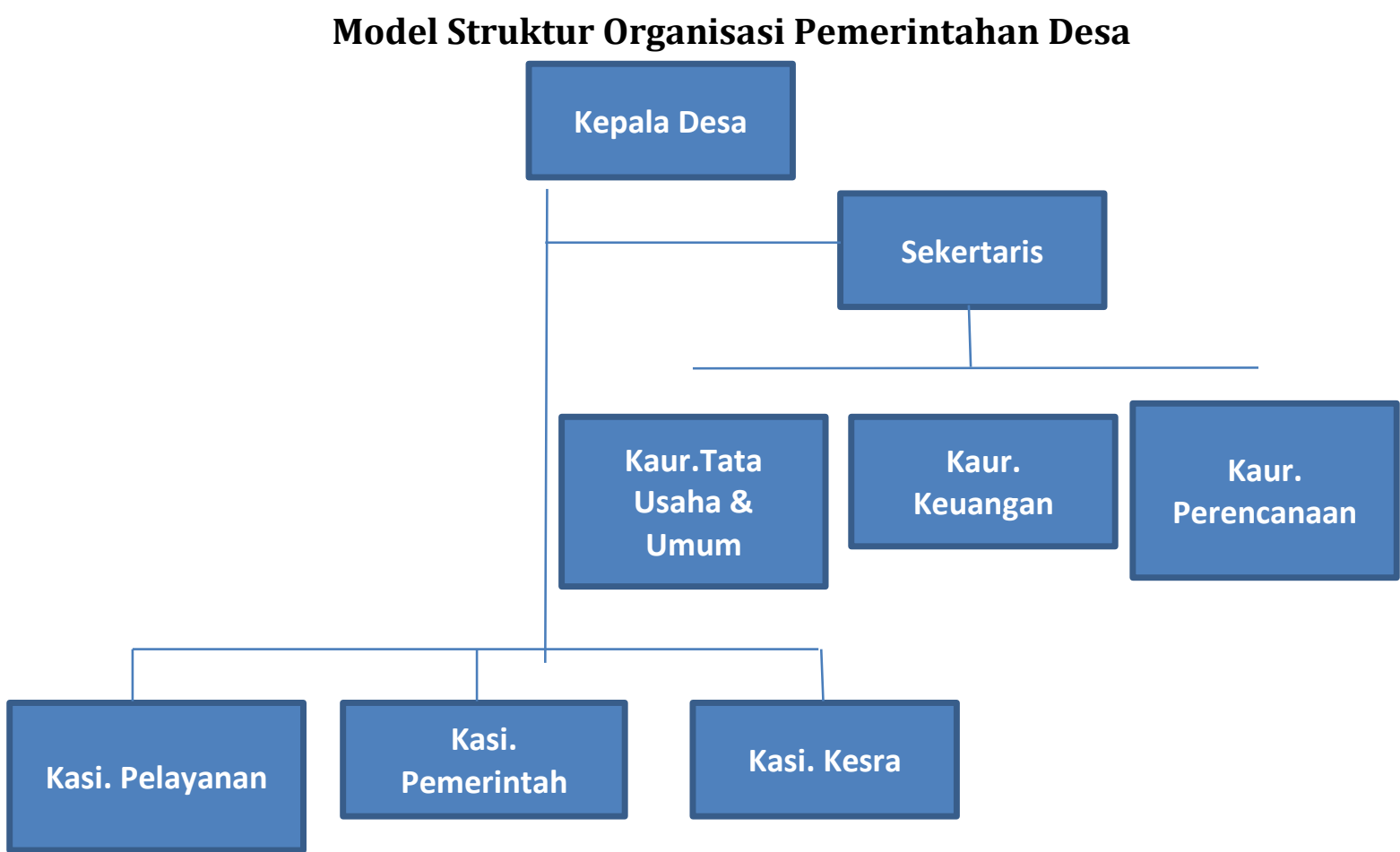

Desa Swasembada menurut Permendagri No. 84 Tahun 2015 Tentang Susunan Organisasi dan Tata Kerja Pemerintah Desa, disebutkan bahwa Desa dengan kriteria Desa Swasembada memiliki 3 unit urusan dan 3 unit seksi dalam struktur organisasinya. Menurut Miztberg, organisasi publik harus memiliki 5 element organisasi. Antara lain strategic apex, midle line, suport staff, technosturcture, dan operating core. Pada gambar diatas model organisasi yang diajukan telah memiliki 5 elemen dasar organisasi publik.

\section{Model Kelembagaan Pemerintah}

\section{Desa Kemuning Berdasarkan}

Permendagri No. 84 Tahun 2015

Permendagri No. 84 Tahun 2015 tentang Struktur Organisasi dan Tata Kerja Pemerintah Desa, menjadi dasar sebuah perubahan struktur organisasi pemerintah Desa. Dengan diberlakunya peraturan tersebut, akan memperjelas kedudukan kewenangan dan pelaksana pelayanan teknis di Pemerintah Desa.

Adapun desain atau model organisasi pemerintah Desa Kemuning yang sesuai dengan Permendagri No. 84 Tahun 2015 tentang Struktur Organsasi dan Tata Kerja Pemerintah Desa sebagai berikut. 


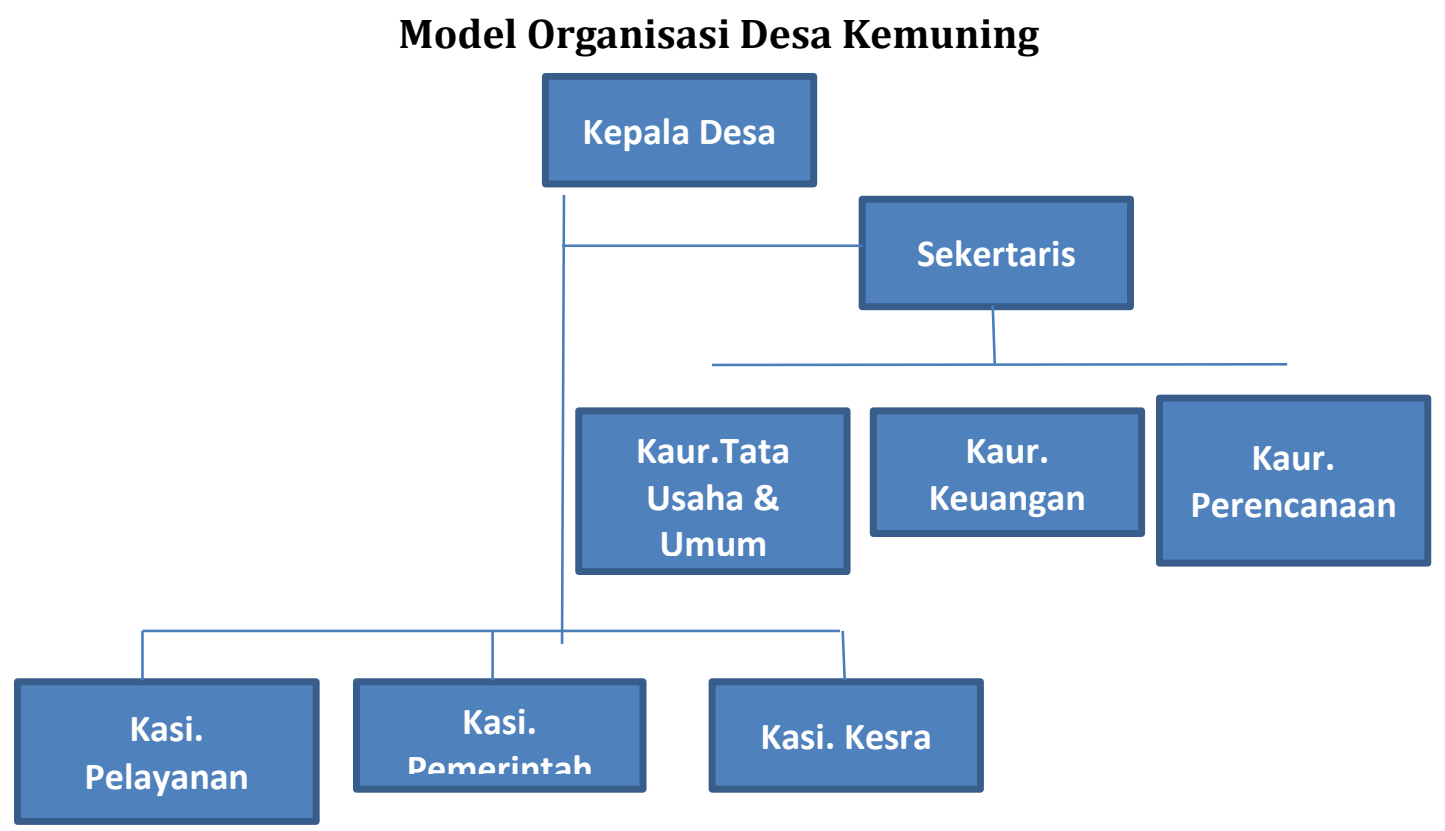

Desa Kemuning merupakan salah satu desa di Kabupaten Tegal yang memiliki kriteria Desa Swakarya, yang berarti bahwa Desa sudah dapat mengelola atau mengatur pemerintah sendiri dan kebutuhan pangan sudah terpenuhi dengan cara pertanian.

Berdasarkan focus group discussion dengan pamong desa dan organisasi kelengkapan desa kemuning, diungkapkan bahwa sementara ini organisasi yang digunakan masih ada kewenangan yang dilaksanakan bukan pada unit organisasinya. Kemudian jumlah sumber daya manusia belum terpenuhi sesuai dengan kriteria (FGD, 14 jan 2016).

Dengan usulan model organsiasi pemerintah desa kemuning yang sesuai dengan Permendagri No. 84 Tahun 2015 tentang Struktur Organisasi dan Tata Kerja Pemerintah Desa, maka pemerintah Desa Kemuning siap untuk melaksanakan perubahan tersebut. Karena perubahan struktur organsiasi berbasis fungsionalis dan dapat menunjang kualitas pelayanan publik sangat diharapkan (FGD, 14 Jan 2016).

\section{Kedudukan dan Fungsi Perangkat Desa Kemuning}

Dalam menjalankan tugasnya Kepala Desa dibantu oleh Perangkat Desa yang kemudian perangkat Desa tersebut menjalankan fungsi unit organsiasi dan kewenangan Desa. Desa Kemuning merupakan salah satu Desa di Kabupaten Tegal dengan kriteria Desa Swakarya dengan skema struktur organisasinya adalah Kepala Desa, Sekertaris Desa dibantu oleh Kaur Umum, Kaur Ke- 
uangan dan Kaur Perencanaan, kemudian unit pelayanan teknis kepada masyarakat terdiri dari Kasi Pelayanan, Kasi Pemerintah, dan Kasi Kesejahteraan Masyarakat.

Unit-unit organisasi tersebut memiliki kewenangan yang berbeda dan tugas yang berbeda. Adapun tugas dan fungsi dari unit organisasi pemerintah Desa Kemuning diuraikan sebagai berikut.

\section{Kepala Desa}

Bertugas sebagai penyelenggara Pemerintahan Desa, melaksanakan pembangunan, pembinaan kemasyarakatan, dan pemberdayaan masyarakat. Dalam melaksanakan tugasnya Kepala Desa memiliki fungsi-fungsi sebagai berikut :

a) Menyelenggarakan Pemerintahan

Desa, seperti tata praja Pemerintahan, penetapan peraturan di desa, pembinaan masalah pertanahan, pembinaan ketentraman dan ketertiban, melakukan upaya perlindungan masyarakat, administrasi kependudukan, dan penataan dan pengelolaan wilayah.

b) Melaksanakan pembangunan, seperti pembangunan sarana prasarana perdesaan, dan pembangunan bidang pendidikan, kesehatan.

c) Pembinaan kemasyarakatan, seperti pelaksanaan hak dan kewajiban masyarakat, partisipasi masyarakat, sosial budaya masyarakat, keagamaan, dan ketenagakerjaan.

d) Pemberdayaan masyarakat, seperti tugas sosialisasi dan motivasi masyarakat di bidang budaya, ekonomi, politik, lingkungan hidup, pemberdayaan keluarga, pemuda, olahraga, dan karang taruna.

e) Menjaga hubungan kemitraan dengan lembaga masyarakat dan lembaga lainnya

\section{Sekertaris Desa}

Bertugas membantu Kepala Desa dalam bidang administrasi pemerintahan. Dalam melaksanakan tugasnya sekertaris Desa memiliki fungsi-fungsi sebagai berikut:

a) Melaksanakan urusan ketatausahaan seperti tata naskah, administrasi surat menyurat, arsip, dan ekspedisi.

b) Melaksanakan urusan umum seperti penataan administrasi perangkat desa, penyediaan prasarana perangkat desa dan kantor, penyiapan rapat, pengadministrasian aset, inventarisasi, perjalanan dinas, dan pelayanan umum.

c) Melaksanakan urusan keuangan seperti pengurusan administrasi keuangan, administrasi sumbersumber pendapatan dan pengeluaran, verifikasi administrasi keuangan, dan 
admnistrasi penghasilan Kepala Desa, Perangkat Desa, BPD, dan lembaga pemerintahan desa lainnya.

d) Melaksanakan urusan perencanaan seperti menyusun rencana anggaran pendapatan dan belanja desa, menginventarisir data-data dalam rangka pembangunan, melakukan monitoring dan evaluasi program, serta penyusunan laporan.

\section{Kaur Tata Usaha dan Umum}

Memiliki fungsi seperti melaksanakan urusan ketatausahaan seperti tata naskah, administrasi surat menyurat, arsip, dan ekspedisi dan penataan administrasi perangkat desa, penyediaan prasarana perangkat desa dan kantor, penyiapan rapat, pengadministrasian aset, inventarisasi, perjalanan dinas, dan pelayanan umum.

\section{Kaur Keuangan}

Memiliki fungsi seperti melaksanakan urusan keuangan seperti pengurusan administrasi keuangan, administrasi sumber-sumber pendapatan dan pengeluaran, verifikasi administrasi keuangan, dan administrasi penghasilan Kepala Desa, Perangkat Desa, BPD, dan lembaga pemerintahan desa liannya.

\section{Kaur Perencanaan}

Memiliki fungsi mengoordinasikan urusan perencanaan seperti menyusun rencana anggaran pendapatan dan belanja desa, menginventarisir data-data dalam rangka pembangunan, melakukan monitoring dan evaluasi program, serta penyusunan laporan.

\section{Kasi Pemerintahan}

Mempunyai fungsi melaksanakan manajemen tata praja Pemerintahan, menyusun rancangan regulasi desa, pembinaan masalah pertanahan, pembinaan ketentraman dan ketertiban, pelaksanakan upaya perlindungan masyarakat, kependudukan, penataan dan pengelolaan wilayah, serta pendataan dan pengelolaan Profil Desa.

\section{Kasi Kesejahteraan}

Mempunyai fungsi melaksanakan pembangunan sarana prasarana perdesaan, pembangunan bidang pendidikan, kesehatan, dan tugas sosialisasi serta motivasi masyarakat di bidang budaya, ekonomi, politik, lingkungan hidup, pemberdayaan keluarga, pemuda, olahraga, dan karang taruna.

\section{Kasi Pelayanan}

Memiliki fungsi melaksanakan penyuluhan dan motivasi terhadap pelaksanaan hak dan kewajiban masyarakat, meningkatan upaya partisipasi masyarakat, pelestarian nilai sosial budaya masyarakat, keagamaan, dan ketenagakerjaan. 


\section{SIMPULAN}

Berdasarkan hasil pembahasan yang telah diuraikan pada bab sebelumnya, dapat disimpulkan bahwa :

1. Desa Kemuning termasuk Desa Swakarya yang merupakan Desa dalam memenuhi kebutuhan pokok sehari-hari berasal dari pertanian yang dikelola secara mandiri dan pola pemikiran masyarakat Desa sudah dipengaruhi oleh lingkungan diluar Desa tersebut.

2. Desa Kemuning dalam pengelolaan organisasi pemerintahan Desa sudah dapat dikatakan mandiri dengan memperkirakan kebutuhan atau desain organisasi yang sesuai dengan kondisi masyarakatnya.

\section{REKOMENDASI}

Dalam mendesain model organisasi pemerintah Desa Kemuning, sebagai acuan dasar yaitu Permendagri No. 84 Tahun 2015 tentang Struktur Organisasi dan Tata Kerja Pemerintah Desa. Berdasarkan dari pembahasan yang diruaikan pada bab sebelumnya, bahwa Desa Kemuning desain organisasi memiliki Unit organisasi antara lain Kepala Desa, Sekertaris Desa, Kaur Umum, Kaur Keuangan, dan Kaur Perencanaan, kemudian untuk unit teknis operasional dinamakan Kasi Pelayanan, Kasi Pemerintah, dan Kasi
Kesejahteraan. Karena menurut Permendagri NO. 84 tahun 2015 tentang Struktur Organisasi dan Tata Kerja Pemerintah Desa, memiliki 3 unit Kaur dan 3 unit Kasi.

\section{DAFTAR PUSTAKA}

Creswell. John W. 2012. Research Design:Pendekatan Kualitatif, Kuantitatif, dan Mixed. Pustaka Pelajar, Yogyakarta.

Gibson, James L., John M. Ivancevich., James H. Donelly Jr. (1995), Organizations, $5^{\text {th }}$ edition, Business Publications, Inc.

Koentjaraningrat. (1990), Pengantar Ilmu Antropologi, Cet-8, Rineka Cipta, Jakarta

Syafiie, Inu Kencana. 1997. Ilmu administrasi publik. Jakarta: Rineka cipta.

Sadjijono, 2008, Memahami Beberapa Bab Pokok Hukum Administrasi Negara, Laks Bang Pressindo, Jogyakarta.

Mercher, Arlyn J. (1994), Struktur dan Proses Organisasi, Rineka Cipta, Jakarta

Mintzberg, Henry. (1979), The Structuring of Organizations, Prentice-Hall, Englewood Cliffs. NJ.Book Review.

Mintzberg, Henry dan James Brian Quin. (1996), The Strategiy Process: Concep, Contexts Cases, PrenticeHall, inc, New Jersey.

Winardi, J. (2004), Manajemen Perilaku Organisasi, Edisi I, Penerbit Prenada Media, Jakarta

Winardi, J. (2011), Teori Organisasi dan Pengorganisasian, Edisi-6, RajaGrafindo Persada, Jakarta. 